\title{
YARGITAY KARARLARI IŞIĞINDA HALİNE MÜNASİP EVİN HACZEDİLMEZLİĞİ (MESKENIYET) İDDİASI (İIK m. 82/12)
}

In the Light of Court Decisions Claim to Abode (Turkish Execution and Bankcrupcy Code Art. 82/12)

Dr. Cenk AKİL

\section{ÖZET}

Borçlu borcunu ifa etmediğinde alacaklılar borçlunun malvarlı̆̆ına müracaat ederler. Borçlunun malvarlığı unsurları alacaklılar bakımından bir nevi teminat teşkil eder. Borçlu borcundan dolayı kural olarak tüm mal, hak ve alacakları ile sorumludur. Bununla birlikte gerek insani düşünceler gerekse kamu düzeni düşüncesiyle borçlunun kendi hayatını ve ailesinin hayatını devam ettirebilmesi için bazı malları hacizden muaf tutulmuştur. Bunlardan biri de İ̈K m. 82/12'de düzenlenmiş bulunan borçlunun hâline münasip evidir. Hâline münasip evi haczedilen borçlu şikâyet yoluna başvurarak evinin haczedilemeyeceğini ileri sürebilir. Bu iddiayı borçlunun yanı sıra aile fertlerinin de ileri sürebileceği kabul edilmektedir. Haczedilmezlik iddiası sadece cüzi icrada değil, külli icrada da ileri sürülebilir.

Anahtar Sözcükler: İcra ve iflâs hukuku, haciz, haczedilemez mülk, hacizden muafiyet, meskeniyet iddiası, haczedilmezlikten feragat 


\begin{abstract}
The creditors recourse to the assets of the debtor when the debtor does not perform his obligation. The elements of the assets of the debtor constitute a sort of guarantee for the creditors. The debtor is liable for his obligation with all of his goods, rights and claims as a rule. However some goods of the debtor are exempted from distraint so that the debtor can continue his and his family's life on the grounds of both humanistic and public order thoughts. One of these goods is the house of the debtor, regulated in the Article 82/12 of the Code of Enforcement and Bankruptcy, which is in accordance with his economic condition. The debtor may assert by having recourse to the remedy of complaint that his house which is in accordance with his economic condition can not be distrained in case his such house is distrained. It is accepted that this claim may be asserted by the members of his family besides the debtor. The claim of non-distrainability can be asserted not only in the debt enforcement but also bankruptcy.
\end{abstract}

Keywords: Execution and bankruptcy law, attachment, unseizable property, exemption from attachment, claim to abode, the cession of exemption from seizure

\title{
GíRiș
}

Haciz konusunda kural, borçlunun malvarlığını teşkil eden mal, alacak ve hakların, alacaklılarına karşı bir tür teminat teşkil etmesi ve bu nedenle (borçlunun) alacaklıları tarafindan borç için haczettirilebilmesidir. Bununla birlikte borçlunun ve ailesinin yaşaması ve ekonomik varlığını devam ettirebilmesi için insani birtakım düşüncelerle istisna olarak, borçlunun bazı mal ve haklarının haczedilemeyeceği kabul edilmiştir (İ̈K m. 82-83) ${ }^{1}$. Bu durum aslında

${ }^{1}$ Baki Kuru, İcra ve İflas Hukuku El Kitabı, İstanbul 2004, s. 437-438; Ömer Ulukap1, Haczedilmezlik ve Haczedilmezliğin "4046 Sayılı Özelleştirme Kanunu" Kapsamındaki Uygulaması (BATIDER 1995/1-2, s. 137-150), s. 137; Bilge Umar, İcra ve İflâs Hukukunun Tarihî Gelişmesi ve Genel Teorisi, İzmir 1973, s. 8 dn. 20. 
AY m. 17 uyarınca herkesin yaşama, maddi ve manevi varlığını koruma ve geliştirme hakkına sahip olmasının, yani kişiliğin ve kişilik haklarının korunmasının icra hukukundaki somut bir görünüm biçimidir ${ }^{2}$. Borçlunun ekonomik değeri bulunan bazı mal, alacak ve haklarının haczi çeşitli düşüncelerle uygun görülmemiştir. Bunlardan birisi kamu düzeni ve yararının korunmasıdır ${ }^{3}$. Gerçekten de bütün malları elinden alınan bir kişi (borçlu) yaşayabilmek için başkalarının haklarına tecavüz etmeye yeltenebilir. $\mathrm{Bu}$ durum ise kamu düzenini bozar ${ }^{4}$. Haczedilemezlik düşüncesinin altında yatan başka bir neden ise alacaklıların menfaatinin korunmasıdır. Borçlunun bütün kazanç yollarının haczedilmesi suretiyle gelir kaynaklarının kurutulması alacaklılar için de zararlıdır. Çalışıp kazanarak borcunu ödeyecek olan borçlunun çalışabilmesi için muhtaç olduğu malların haczedilmemesinde alacaklıların da menfaati vardır 5 . Nihayet, borçluyu her şeyini haczederek muhtaç bir duruma sokmak, insani duyguları incitir. Yaşamak en temel hak olduğundan, bu hakkın bir alacaklının şahsi yararı uğruna feda edilmesi doğru değildir ${ }^{6}$.

Evin haczedilmezliği (meskeniyet) iddiası tamamı haczedilemeyen mal ve hakların 12 bent hâlinde sayılmış olduğu İIK m. 82'nin birinci fikrasının son bendinde düzenlenmiştir ${ }^{7}$. Bu maddedeki mal ve haklar, borçlu ve ailesinin yoksul kılınıp, sonuçta devletin sosyal yardımına muhtaç bırakılmaması ve borçlunun ekonomik varlığını devam ettirebilmesi düşüncesine dayanarak haczedilmez sayılmıştır ${ }^{8}$. Ev, hayatın

${ }^{2}$ Bkz. ve karş. Muhammet Özekes, İcra Hukukunda Temel Haklar ve İlkeler, Ankara 2009, s. $152 \mathrm{vd}$.

3 Mustafa Reşit Belgesay, İcra ve İflas Kanunu Şerhi, 4. B., İstanbul 1954, s. 166; Necmeddin Berkin, Haczi Caiz Olmayan Eşya ve Alacaklar (İBD 1957/5, s. 113-124), s. 113; Ulukap1 s. 138.

${ }^{4}$ Belgesay s. 166; Berkin-Makale s. 113; Ulukap1 s. 139

${ }^{5}$ Berkin-Makale s. 113; Belgesay s. 167.

${ }^{6}$ Berkin-Makale s. 114; Ulukap1 s. 141.

${ }^{7}$ Belirtmek gerekir ki, İ̈K m. 82, I/12'ye paralel bir düzenleme AATUHK m. 70, I/11'de de yer almaktadır. Bahsi geçen maddeye göre " Borçlunun haline münasip evi ancak evin değeri fazla ise bedelinden haline münasip bir yer alınabilecek miktarı borçluya bırakılmak üzere haczedilerek satılabilir".

${ }^{8}$ Kuru-El Kitabı s. 439; İlhan Postacioğlu, İcra Hukuku Dersleri, İstanbul 1982, s. 330; Ziynet Seldağ Ceylan, Haczedilmezlik ve Kısmen Haczedilmeyen Mallar (TNBD 
idamesinde çok önemli bir yere sahip olduğundan ev haczi başvurulabilecek son çare olarak kabul edilmektedir'. Evin haczedilmezliği (meskeniyet) iddiası hem cüzi icrada hem de külli icrada ileri sürülebilir ${ }^{10}$.

\section{HÂLINE MÜNASIPP EV KAVRAMI}

İK m. 82/12 $2^{11}$ uyarınca borçlunun hâline münasip evi haczedilemez ${ }^{12}$. Buradaki evden maksat yerel geleneklere göre mesken (konut) olarak kullanılmaya everişli olan yerlerdir. Bu bağlamda, bağımsız ev ${ }^{13}$, barınak $^{14}$, bağ evi ${ }^{15}$, kat mülkiyeti buradaki ev tabirine dâhildir.

2001/109, s. 51-57), s. 52. Borçlunun hâline münasip evinin haczin dışına çıkarılması aslında oranlılık ilkesinin cebri icra hukukundaki görünüm biçimlerinden biridir. Bkz. Meral Sungurtekin Özkan, İcra Hukukunda Oranlılık İlkesi (Turan Tufan Yüce'ye Armağan, İzmir 2001, s. 177-203), s. 198; Kudret Aslan, Hacizde Sira (Tertip) (AÜHFD, 2005/2, s. 269-318), s. 308-309. İcra hukukunda oranl1l1k ilkesi hakkında geniş bilgi için ayrıca bkz. Kamil Yıldırım, İcra Hukukunun Anayasa ile İlişkisi ve Ölçülülük İlkesi (HAD, 1989/1-3, s. 98-115), s.103 vd.; Özekes s. 205 vd.

9 Yildırım s. 108

${ }^{10}$ Baki Kuru, Haczi Caiz Olmayan Şeyler (AÜHFD 1962/1-4, s. 277-326), s. 278; Ceylan s. 52; Nazif Kaçak, Açıklama ve İçtihatlarla Haczedilmezlik, Ankara 2006, s. 16.

${ }^{11} \mathrm{Bu}$ bent İsviçre hukukunda yer almamaktadır (Saim Üstündağ, İcra Hukukunun Esasları, 8. B., İstanbul 2004, s. 183).

${ }^{12}$ Borçlunun hâline münasip evi iflas masasına da girmez. Bununla birlikte, müflis mülkiyetinde hâlihazırda hâline münasip bir evi bulunmasına rağmen, çalışmasına dayanan ücret karşılığının haczedilemeyen kısmıyla ikinci bir yeni evin mülkiyetini edinirse, tasfiye dışı ücret geliriyle satın alınsa ve bu nedenle ikame mal sayılsa bile, ikinci evin mülkeyitine sahip olunması, haczedilebilirlik sınırını aşmış olduğundan masaya girer ve tasfiyeye tâbi tutulur (Ahmet Başözen, İflas Tasfiyesinde Müflisin Kişisel Çalışmasına Dayalı Malların Durumu - "Müflisin Uhdesine Geçen Mal" Kavramı (İ̈K m. 184, I) (AÜHFD, C. 54, 2005/4, s. 267-297), s. 288).

${ }_{13}^{13}$ Ömer Ulukapı, İ́cra ve İflas Hukuku, Konya 2001, s. 83 dn. 120.

14 “....Meskeniyet itirazında bulunulan ev mahkemece haczin kaldırılmasına karar verilen 1859 nolu parsel içinde bulunmaktadır. Bilirkişi raporunda, evin minimum şartlarda barınmayı sağladığı belirtilmektedir. Açıklanan nedenle; ev ile ilgili meskeniyet iddiasının kabulüne karar verilmesi gerekirken, ev ayrı tutularak yazılı şekilde evin barınak olduğu, bir ailenin oturmasına münasip mesken niteliğinde bulunmadı̆̆ından bahisle meskeniyet iddiasının reddine karar verilmesi isabetsizdir..." (12. HD 31.1.2005 2976/6893: Talih Uyar, İcra ve İflas Kanunu Şerhi, C. V, Ankara 2004, s. 7251-7252). 
Kanunda geçen "hâline münasip ev"in ne olduğu borçlunun aylık geliri, sosyal statüsü, aile fertlerinin sayısı itibarıyla küçük veya büyük bir eve ihtiyacı olup olmadığı gibi veriler dikkate alınıp incelenerek tespit edilmelidir $^{16}$. Örneğin borçlu ve ailesi bakımından makul ölçüleri aşan oda ve salona sahip olan ve ikamet için zorunlu öğeleri aşan yerler maddede belirtilen "hâline münasip ev" kriterinin dışında kalır. Borçlunun görev ve sıfatı da tek başına az önce belirtilen nitelikleri aşan görkemli bir evde ikamet etmesini gerektirmez ${ }^{17}$. Bu konuda Yargitay farklı yönde kararlar vermiştir. Yargıtay eski bir kararında borcunu ödemekle yükümlü olan borçlunun mütevazi bir hayat sürmesinin, meskenini bu şartlar dahilinde seçmesinin gerekeceğini; mahcuz üzerindeki haczedilmezlik iddiasının bu açıdan incelenmesi gerektiğini ifade etmiştir ${ }^{18}$. Yargıtay daha sonra vermiş olduğu kararlarında ise borçlunun mevcut sosyal statüsünden daha kötü bir hâle gelmesine neden

15 “...Taşınmazın bağ evi olarak kullanılması ve tapuda bă̆ olarak gözükmesi İIK. 82. maddesine göre meskeniyet şikâyetinde bulunulmasina engel teşkil etmez. Ayrıca taşınmazın paylı olması dahi payına isabet edecek miktar esas alınarak aynı madde uyarınca meskeniyet şikâyetinin incelenmesine mani değildir..." (12. HD 2.10.1996, 10745/11547: Gündüz Pehlivanlı, Açıklamalı İcra ve İflas Kanunu, Ankara 1998, s. 655).

${ }^{16}$ Timuçin Muşul, İcra ve İflâs Hukuku, 3. B., İstanbul 2008, s. 517; Kamil Yıldırım / Nevhis Deren-Yıldırım, İcra Hukuku, 4. B., İstanbul 2009, s. 145.

${ }^{17}$ Yıldırım / Deren-Yıldırım s. 145. “...IIIK'nın 82/12 maddesi gereğince, borçlunun "hâline münasip" evi haczedilemez. Bir meskenin borçlunun hâline uygun olup olmadiğ adı geçenin haciz anındaki sosyal durumuna ve borçlu ile ailesinin ihtiyaçlarına göre belirlenir. Buradaki "aile" terimi, geniş anlamda olup, borçlu ile birlikte aynı çatı altında yaşayan, bakmakla yükümlü olduğu kişileri kapsar. İcra mahkemesince, borçlunun sözü edilenlerle birlikte barınması için zorunlu olan hâline münasip meskeni temin etmesi için gerekli bedel bilirkişilere tespit ettirildikten sonra, haczedilen yerin klymeti bundan fazla ise satılmasına karar verilmeli ve satıs bedelinden yukarıda nitelikleri belirlenen mesken için gerekli olan miktar borçluya birakılmalı, kalanı alacakliya ödenmelidir. Bu kıstasları aşan nitelik ve evsaftaki yerlerle, makul ölçüleri geçen oda ve salonu kapsayan, ve ikamet için zorunlu öğeleri içeren bir meskenin dışındaki yerler, maddede öngörülen amaca aykırıdır. Borçlunun görev ve sıfatı, kendisinin yukarlda belirlenenden daha görkemli bir meskende ikamet etmesini gerektirmez..." (12. HD 23.01.2007, 2006/23100-822: http://www.hukukturk.com).

18 İID 13.5.1954 1988/2307 (Sema Taşpınar, Borçlunun Bazı Mallarının Haczedilememesi ve Nedenleri (Haczedilmezlik ve Nedenleri), (Yayımlanmamış Yüksek Lisans Tezi), Ankara 1994, s. 172). 
olunamayacağını, dolayısıyla örneğin şehir merkezinden uzak bir yerde ya da gecekondu bölgesinde oturmaya zorlanamayacağını dile getirmiştir ${ }^{19}$. Kanımızca da Yargıtay'ın yeni tarihli kararları daha doğrudur. Nitekim Kanun'da da borçlunun "hâline münasip" evinin haczedilemeyeceği ifade edilmiştir ${ }^{20}$. Bununla birlikte bu konuda abartıya da kaçılmamalıdır. Bu anlamada olmak üzere borcunu ödemeyerek icra takibine maruz kalan ve alacaklının hakkına kavuşmasını engelleyen borçlunun borcundan önceki lüks ve görkemli yaşantısını devam ettirmesi de kabul edilemez ${ }^{21}$.

Borçlunun "hâline münasip" evi belirlenirken onun birlikte yaşadığı ailesinin durumu da göz önünde bulundurulacaktır. Borçlunun ailesinden kast kural olarak borçluyla birlikte yaşayan, borçlunun bakmakla yükümlü olduğu kişilerdir ${ }^{22}$. Yargıtay takip borçlusunun evli kızı ile damadının da onunla birlikte yaşaması durumunda borçlunun ev ihtiyacı belirlenirken bu kişilerin de hesaba katılmaları gerektiği yönünde karar vermiştir $^{23}$. Öğretide bu görüş eleştirilmiş ve haczedilmezlik

19 “....Müştekinin şimdiye kadar normal bir dairede ikamet etmekte olup sosyal yaşantısını buna göre devam ettirdiği cihetle, gecekondu sayllabilecek bir yerde ikamet edemeyeceği düşünülmeksizin...” (12. HD 13.2.1987 6536/1797 (Taşpınar s. 172). Bununla birlikte Yargıtay'ın şu kararına katılmaya imkân yoktur: “...İki mahâllede evi bulunan borçlunun ötedenberi ikamet etmekte olduğu mahâlledeki evin kendisine mesken olarak bırakılması lazım gelip diğer mahâlledeki evde oturmă̆a icbar edilemez..." (IIID 25.4.1944: Aytemiz, Abdullah : Takip Hukuku ile Alakalı Temyiz Karar ve İçtihatları, Ankara 1944, s. 36). Kanımızca bu tip bir genelleme yapılamaz. Öteden beri ikamet etmekte olduğu evin bedeli yüksek ise ve diğer mahâllede bulunan ev de borçlunun hâline münasip ise borçlunun ikamet ettiği evin haczedilerek paraya çevrilmesi ve diğer evin borçluya bırakılması mümkündür.

${ }^{20}$ Taşpınar-Tez s. 172.

${ }^{21}$ Mehmet Yalçın, İcra ve İflas Hukukunda Mesken Haczi (Yayımlanmamış Yüksek Lisans Tezi), İstanbul 2009, s. 48.

22 “...IİK'nun 82/12 maddesi gereğince, borçlunun "hâline münasip” evi haczedilemez. Bir meskenin borçlunun hâline uygun olup olmadiğl adı geçenin haciz anındaki sosyal durumuna ve borçlu ile ailesinin ihtiyaçlarına göre belirlenir. Buradaki "aile" terimi, geniş anlamda olup, borçlu ile birlikte aynı çatı altında yaşayan, bakmakla yükümlü olduğu kişileri kapsar..." (12. HD 27.2.2007, 630/3339: Mustafa Oskay, Mustafa / Coşkun Koçak / Adnan Deynekli / Ayhan Doğan, İİK. Şerhi, C. 2, Ankara 2007, s. 2366).

23 İiD 13.5.1954, 1988/2307 (Üstündağ s. 184). 
durumlarında borçlunun ailesi geniş anlamda anlaşılabilir ise de kararda söz konusu olan kişiler borçlunun kanunî olarak bakmakla yükümlü olduğu kişilerden sayılamayacağı gibi geleneklere göre de evli kız ve damadın o aileden olduğunun kabul edilemeyeceği belirtilmiştir ${ }^{24}$. Kanımızca aile fertleri belirlenirken peşin bir hüküm verilemez. Borçlunun ailesinin kimlerden oluştuğu tespit edilirken borçlunun bulunduğu yörenin gelenekleri de göz önünde bulundurulmalıdır. Borçlunun içinde bulunduğu tüm öznel koşullar göz önünde tutularak aynı çatı altında borçlu ile birlikte bulunan kişilerin aile ferdi sayılıp sayılmayacağ karara bağlanmalıdır $^{25}$.

İki ev için haczedilmezlik iddiasında bulunulabilir mi? Yargıtay vermiş olduğu bir kararında haklı olarak borçlu ve ailesinin gereksinimine yanıt verecek ise borçlunun iki evi için de haczedilmezlik şikâyetinde bulunup bulunamayacağının araştırılmasının gerekeceğine değinmiştir ${ }^{26}$. Taşınmazlar farklı takip dosyalarında haczedilmiş olması durumunda dahi iki taşınmazdan biri hakkında haczedilmezlik iddiası ileri sürülebilirir ${ }^{27}$.

Şayet borçlu ev sahibi olmakla birlikte kendisi de kirada oturmakta ise Yargıtay kira parasının da haczedilemeyeceğine karar vermiştir. Yargıtay'ın bu kararı öğretide eleştirilmiş ve Kanun'un amacının bir meskende oturan borçlu ve ailesinin buradan yoksun kılınmaması olduğu; yoksa kiraya vermiş olduğu evinden elde ettiği kira gelirinin de haczedilmemesinin öngörülmediği ifade edilmiştir ${ }^{28}$. Kanımızca Yargıtay'ın görüşü isabetlidir. Zira böyle bir durumda her ne kadar takip borçlusu kira geliri elde etmekteyse de kendisi de kiracı olduğundan ve kira parası ödediğinden elde ettiği kiranın haczedilememesi gerekir. Fakat bunun için ödediği kira ile elde ettiği kira arasında önemli bir fark

\footnotetext{
${ }^{24}$ Taşpınar-Tez s. 172.

${ }^{25}$ Karş. Murat Dönmez, İcra ve İflâs Hukukunda Meskeniyet İddiası (İIK m. 82/12), İzmir 2009, s. $21 \mathrm{vd}$.

26 "...İki evli, çocuk ve torun sahibi olduğunu söyleyen borçlunun iki eve ihtiyacı olup olmadı̆̆ tahkik ve tetkik olunmak lazımdır...”. İ̈D 26.9.1941 (Aytemiz s. 32).

${ }^{27}$ Oskay / Koçak / Deynekli / Doğan s. 2345.

${ }^{28}$ Taşpınar-Tez s. 173.
} 
bulunmamalıdır. Borçlunun elde ettiği kira geliri ödediği kiradan ciddi düzeyde yüksek ise aradaki fark haczedilebilmelidir.

Borçlunun kira ile ev tutabilecek güçte olması haczedilmezlik şikâyetinde bulunmasına engel midir? Yargıtay bu soruya haklı olarak olumsuz cevap vermiştir ${ }^{29}$. Zira Kanun'da borçlunun hâline münasip evinin haczedilemeyeceği ifade edilmiştir. Bundan kasit borçlunun mülkiyetindeki evdir.

Öğretide ve yarg1 kararlarında Kanun'da geçen “ev" tabirinden konut olarak kullanılmaya elverişli yerlerin kastedildiği; taşınmazın tapu kaydında arsa veya tarla olarak gözükmesinin, üzerinde mesken bulunması hâlinde haczedilmezlik şikâyetinde bulunulmasına engel olmayacağ $1^{30}$; haczedilmezlik şikâyetinin mevcut ve oturmaya uygun bir evin bulunması hâlinde yapılabileceği; henüz mesken olarak kullanılabilir bir durumda bulunmayan taşınmazın haczedilmezlik şikâyetine konu edilemeyeceği ${ }^{31}$ kabul edilmektedir ${ }^{32}$. Buna karşıllk, haciz tarihinden önce arsa üzerine bina inşa edilmiş olması durumunda ise borçlunun böyle bir ev için haczedilemezlik iddiasında bulunabileceği kabul edilmektedir ${ }^{33}$.

Borçlu haczedilmezlik iddiasında bulunduğu ev üzerindeki mülkiyet hakkına tek başına sahip olmak zorunda değildir. Diğer bir deyişle, borçlu, müşterek veya iştirak hâlinde malik olduğu ev için de

\footnotetext{
${ }^{29}$ 12. HD 3.6.1992, 629/7692 (Pehlivanl1 s. 663).

${ }^{30}$ Yıldırım / Deren-Y1ldırım s. 146.

31 “...Dosyada mevcut 2.2.1996 tarihli bilirkişi raporu içeriğine göre meskeniyet şikâyetine konu edilen 2 nolu meskeni inşaatının \% 65 nin tamamlandiğg dolayısıyla haciz tarihinde henüz mesken olarak kullanılabilir durumunun bulunmadığ anlaşılmaktadır. Bilirkişi raporunda inşaatın tamam olduğu varsayımına dayalı olarak değerlendirme yapılarak sonuca gidildiği ve mercice de bu rapor ile değerde değişiklik yapan raporun esas alınarak hüküm kurulduğu görülmektedir. Henüz mesken olarak kullanılabilir durumda bulunmayan taşınmazın meskeniyet şikâyetine konu edilemeyeceği cihetle...” (12. HD 22.5.1996, 6810/6879: Oskay / Koçak / Deynekli / Doğan s. 2479-2480).

32 Oskay / Koçak / Deynekli / Doğan s. 2344.

33 İİD 31.5.1955, 1540/1496 (Senai Olgaç / Haydar Köymen, Kazai ve İlmi İçtihatlarla: Türk İcra ve İflas Kanunu, 2. B., İstanbul 1965, s. 716).
} 
haczedilmezlik iddiasında bulunabilir ${ }^{34}$. Bu durumda borçlunun pay değeri belirlenerek evin hâline uygun olup olmadığı tespit edilecektir ${ }^{35}$. Ortaklığın giderilmesi (izale-i şüyu) davasının açılmış olması da haczedilmezlik iddiasına engel olmaz ve buradan elde edilecek bedelin borçlunun durumuna uygun bir ev almaya yetip yetmeyeceği araştırılır ${ }^{36}$.

Borçlunun haczedilmezlik iddiasında bulunduğu evin muhakkak tapuda kayıtlı olması zorunlu değildir. Gecekondunun dahi haczedilmezliği ileri sürülebiliri ${ }^{37}$.

Borçlunun haczedilmezliğini ileri sürdüğü evde bizzat oturması gerekmemektedir. Borçlu, kiraya vermiş olduğu evi hakkında da haczedilmezlik iddiasında bulunabilir.

Borçlunun tek bir tapu ile sahip bulunduğu taşınmaz üzerinde birden çok bina, örneğin bir ev, fabrika ve ayrıca boş bir ev arsası veya bahçe varsa ve imar mevzuatına göre bölünmesi (parsellere ayrılması) mümkün ise borçlunun durumuna uygun evinin bulunduğu arsa bölünür, yani bu ev

\footnotetext{
${ }^{34}$ Taşpınar s. 169. “... IIIK.'nun 82/12. maddesi dayanak yapılıp haczedilmezlik şikâyetine konu teşkil eden takınmazın 3/4 hissesi muris adına kayıtlı olup mirasçıların bu pay üzerinde iştirak hâlinde malik bulundukları anlatılmaktadır. Dairemizin öteden beri istikrarlı biçimde uygulanan yerleşik içtihatlarına göre iştirak hâlinde malik olan borçluların paylarının haczedilmesi nedeniyle meskeniyet şikâyetinde bulunabilecekleri kabul edilmektedir...” (12. HD 8.5.2007, 6939/9356: http://www.hukukturk.com).

35 “...Dairemizce de kabul edildiği üzere paylı taşınmazlarda paydaş şikâyetçinin meskeniyet iddiasında bulunmasina yasal bir engel yoktur. Bu durumda iddia, yasal pay oranı esas alınarak çözülür. Yani borçlunun ölmüs bulunan babasından intikal eden evi ile ilgili olarak alınacak veraset belgesi dikkate alınmak suretiyle borçluya isabet edecek paya isabet eden değer bilirkişiye tespit ettirilerek borçlunun sosyal durumu itibart ile oturabileceği bir mesken alması için gerekli bedelden az olup olmadı̆̆ incelenmeli...” (12. HD 5.10.2006, 14770/18318: Oskay / Koçak / Deynekli / Doğan s. 2389).

${ }^{36}$ 12. HD 8.4.1980 1634/3292 (Uyar-Haciz s. 688-689).

37 Oskay / Koçak / Deynekli / Doğan s. 2345. “...Borçlu haricen satın aldığ tapulu taşınmazın üzerine gecekondu inşa etmiştir. Gecekondu enkazının haczine yasal bir engel yoktur. Gecekondu 13.500.000 lira klymetinde $45 \mathrm{~m}^{2}$ alanl bir katl iki oda ve basit bir mutfaktan ibaret olup, borçlunun ve ailesi efradının asgari mesken ihtiyacını karşılayacak niteliktedir. Arsanın 3. Şahıs adına tapuda kayıtlı olması meskeniyet şikâyetinde bulunmasina engel değildir..." (12.HD 6.7.1993, 8004/12175: Uyar-V s. 7275).
} 
için ayrı bir tapu çıkarılır ve bu ev borçluya bırakıldıktan sonra taşınmazın kalan kısmı haczedilip satılır. Bölünme işleminin yapılması borçluya aittir. Bunun için icra dairesi borçluya bu işlemi yaptırması amacıyla uygun bir süre verir. Borçlu, bu süre içerisinde bölünme işleminin yapıldığını tapu kayıtları ile kanıtladığı takdirde, ev dışında kalan taşınmazlar satılır. Şayet borçlu, verilen süre içerisinde bölünme işlemini yaptırmazsa, tek tapuya bağlı taşınmazın tamamı satılarak elde edilen bedelden borçluya mesken ihtiyacını giderecek para verildikten sonra arta kalan para alacakl1lara ödenir ${ }^{38}$.

Yargı kararlarında sadece temelden ibaret yapısı bulunan boş arsa hakkında ileride oraya ev inşa edileceği iddiasıyla haczedilmezlik şikâyetinde bulunulamayacağı kabul edilmektedir ${ }^{39}$. Kanımızca bu tip durumlarda yapılacak keşif ve bilirkişi incelemesi sonucunda takip borçlusunun söz konusu arsa üzerinde ev (mesken) olarak kullandığı bir yapının olup olmadığı araştırmalıdır. Böyle bir yer yok ise boş arsa satılıp paraya çevrilecekse de bundan takip borçlusuna hâline münasip bir ev alacak kadar meblağ ayrılmalıdır.

Evin borçlunun hâline münasip olup olmadığı belirlenirken hem objektif hem de sübjektif kriterlere başvurulmalıdır. Buna göre borçlunun barınma amacıyla kullandığ 1 yerin neresi olduğu onun sübjektif iradesine göre belirlenmeli ${ }^{40}$ ve yapılan keşif sonucunda bu yer objektif olarak "hâline münasip" sayılabiliyorsa onun evi kabul edilmelidir ${ }^{41}$. Bu

\footnotetext{
${ }^{38}$ Postacıŏlu s. 364; Kuru-Makale s. 310-311; Taşpınar-Tez s. 167-168.

39 12. HD 20.12.2002 25871/27070 (Uyar-V s. 7267).

40 Nitekim Yargıtay vermiş olduğu bir kararında haklı olarak "mandıranın" da ev (mesken) sayılabileceğine dikkat çekmiştir: “...Aynı zamanda borçlu ve ailesi efradının süknalarına mahsus olduğu anlaşılan mahcuz mandıranın mesken ihtiyacını karşılayıp karşılayamayacağ hâllerine münasip bir ev bedelinin tefriki mümkün olup olmadığ usulü dairesinde seçilecek bilirkişi marifetiyle tetkik ve tesbit edildikten sonra işin karara bağlanması gerektiği hâlde..." (İID 20.4.1950 1879/2087: Uyar-V s. 7284).

41 Örneğin bir Yargıtay kararında borçlunun orta katını mesken olarak kullandığı bir binanın kat mülkiyetine veya kat irtifakına geçirilmemiş olmasının onun meskeniyet iddiasının dinlenmesini engellemeyeceği kabul edilmiştir (Uyar-V s. 7271). “...Ş̧ikâyete konu taşınmazın bir bölümünün lokanta olarak kullanıldığı anlaşılmaktadır. Borçlunun aile durumu nazara alınarak taşınmazın tümünün borçlunun mesken ihtiyacından fazla
} 
bağlamda mesken kavramına çadır, çardak, kayık, samanlık gibi kötü hava koşullarından ve tehlikelerden korunmaya elverişli, bireyin özel hayatını sürdürdüğ̈̈ yerler de dâhildir ${ }^{42}$.

Kanımızca borçlunun evin haczedilmezliği iddiasını ileri sürmesi için onun herhangi bir taşınmaza malik olması gerekmemektedir. Bize göre evin haczedilmezliği (meskeniyet) iddiası somut değil; soyut bir iddiadır. Bu bağlamda, örneğin, kirada oturmakla birlikte bir bankada yüklü miktarda hesabı bulunan ve bu hesabına haciz konulan bir borçlu da meskeniyet iddiasında bulunabilmelidir. Böyle bir durumda da onun hâline münasip bir ev alabilmesi için gerekli olan miktar ayrılmalı ${ }^{43}$; takip alacaklısının alacağı bakiye mevduat üzerinden karşılanmalıdır. Zira burada amaç borçlu ve ailesinin mağdur edilerek devletin sosyal yardımına muhtaç hâle getirilmemesidir. $\mathrm{Bu}$ bakımdan fiilen hâline münasip ev sahibi olan borçlu ile ev sahibi olmayan ve fakat malvarlı̆̆ 1 hâline münasip ev almaya yeten borçlu arasında ayırım yapmak sağlam temellere dayanmamaktadır. Bunun yanı sira yapılacak bir kanun değişikliği ile kendisine ait bir evi olmayan yoksul borçlunun gelirine haciz konulmuş ise onun hâline münasip ev kiralayabilmesi için gerekli olan meblağın da hacizden muaf tutulması kabul edilmelidir.

olup olmadĭ̆ı, başka bir deyimle borçlunun, taşınmazın bir bölümünü mesken ihtiyacından fedakârlık ederek mi lokanta olarak kullandiğg, yoksa lokanta olarak kullanılan kısmin mesken ihtiyacından fazla bölüm olup olmadı̆̆ tespit edildikten sonra, oluşacak duruma göre bir karar vermek gerekirken eksik inceleme ile yazıl şekilde karar verilmesi isabetsizdir..." (Uyar-V s. 7271-7272).

42 Taylan Özgür Kiraz, İsviçre Federal Mahkemesinin Bir Kararı Çerçevesinde Takip Hukukunda Şikâyet Eden Taraf Bakımından İlgili Kavramı (Prof. Dr. Bilge Öztan'a Armağan, Ankara 2008, s. 561-566), s.561-562.

43 İsviçre İcra ve İflas Kanunu'nda yapılan değişiklik sonucu haczedilemeyen fakat çok değerli olan veya borçluya yatırım (plasman) olarak hizmet eden şeylerin, aynı türden daha ucuz bir şeyle ikame edilmesi ya da bunun elde edilmesi için gereken paranın borçluya bırakılması olanağının alacaklıya tanınması mümkün hale gelmiştir (İsv. İ̈K m. 92, I/1-3). Bkz. Sema Taşpınar, İsviçre Federal İcra ve İflâs Kanunu'nda Yapılan Değişikliklere Genel Bir Bakış (75. Yaş Günü İçin Prof. Dr. Baki Kuru Armağanı, Ankara 2004, s. 599-670), s. 621-622. 
Öğretide ${ }^{44}$ ve yarg1 kararlarında takip borçlusunun kötü niyetli olması hâlinde meskenin haczedilemezliğinden faydalanamayaca $\breve{g}_{1}{ }^{45}$, örneğin, evini alacaklılardan mal kaçırmak için satan borçlunun bu satışın iptali hâlinde haczedilmezliği ileri süremeyeceği kabul edilmiştir. Kanımızca borçlunun bu konudaki niyeti haczedilmezliğin tespitinde rol oynamaz. Diğer deyişle, burada sübjektif değil, objektif kriterler dikkate alınmalıdır. Şayet borçlunun alacaklılarından kaçırmaya çalıştığı ev, objektif kriterlere göre yapılan değerlendirme neticesinde "hâline münasip ev" olarak nitelendirilebiliyorsa onun haczedilmezlik iddiasında bulunabilmesine müsaade etmek gerekir.

\section{II. İCRA MEMURUNUN HACZEDILMEZLIK KONUSUN- DAKİ YETKİSI}

Yargıtay'a $^{46}$ ve öğretide temsil edilen bir görüşe göre ${ }^{47}$ icra memurunun haciz sırasında borçlunun hâline münasip olduğunu iddia ettiği evini haczetmekle yükümlü olup; onun bu konuda takdir yetkisi bulunmamaktadır. $\mathrm{Bu}$ görüşe göre icra memurunun evi haczetmesi üzerine takip borçlusu evinin haczedilemeyeceğini ileri sürerek şikâyet

${ }^{44}$ Necmeddin Berkin, Tatbikatçılara İcra ve İflas Hukuku Rehberi, İstanbul 1980, s. 216; Halit Korkud, Haciz Edilen Gayrimenkullerde Meskeniyet İddia ve Şikâyetleri (İBM 1944/4, s. 193-195), s. 195.

45 “...Alacakliyı izrar kasdiyle borçlu tarafindan başkasına satılmış olan ev hakkındaki ferağ muamelesinin mahkemece iptalinden sonra icra dairesince haczolunan mezkur eve müteallik olarak dermeyan edilecek meskeniyet iddiası dinlenmez..." (IIID 7.8.1940: Vasfi Raşit Seviğ, Doktrin ve İçtihatlar Açısından Türk İcra ve İflâs Kanunu, Ankara 1967, s. 97). Ancak bu müeyyide ancak borçlu hakkında uygulanır. Borçlunun mirasçıları yine de bu mallar hakkında haczedilmezlik iddiasında bulunabilirler (Üstündağ s. 189).

46 “...İcra ve Iflas Yasası'nın 79. maddesinde, gerekse 85. madde ifadesinden ortaya çıkan sonuç, icra müdürüne haciz uygulaması konusunda bir takdir yetkisi tanınmadı̆̆ $ı$ dır. Gerçekten de 79. madde kesin bir ifade ile icra dairesinin haczi yapacă̆ından, 85. madde yasal koşullar altında (borçlunun) mal ve alacaklarının haczolunacağından söz etmektedir. 85. madde sadece (alacaklara yetecek miktarın) saptanması konusunda icra müdürüne bir takdir yetkisi tanımaktadır. Ayrıca, icra müdürü haciz işlemini yaparken (haciz tarihinde) taşınmazın (borçlu adına) kayıtlı olması zorunlu ve yeterlidir..." (12. HD 11.9.2007, 14544/16109: Dönmez s. 7).

${ }^{47}$ Talih Uyar, Haczi Caiz Olmayan Mallar ve Haklar (Recai Seçkin'e Armağan, Ankara 1974, s. 551-586), s. 582; Necmeddin Berkin, İcra Dairelerinin Faaliyetini Tanzim Eden Hükümler (Ï̈HHFM 1976/1-4, s. 201-232), s. 207-208; Yalçın s. 83. 
yoluyla icra mahkemesine başvuracak ve bu konuda son sözü icra mahkemesi söyleyecektir ${ }^{48}$. Belirtmek gerekir ki, Yargıtay'ın görüşü öğretide "icra memurunun İcra ve İflas Kanunu hükümlerini birinci derecede uygulamakla yükümlü olduğu ilkesi”ne aykırı bulunmakla beraber icra memuru, haczedilmezlik kararına karşı yapılacak şikâyetin incelenmesine kadar borçlunun evini satıp devretmesini engellediğinden bu görüş pratik ihtiyaçlara uygun bulunmuş ve buna gerekçe olarak da bu suretle icra memurunun bir takdir hatası sonucunda haczi caiz olan evin haczinin caiz olmadığına karar vermesi hâlinde, icra mahkemesinin bu hususta karar vermesine kadar borçlunun evini başkasına devretmesinin engellenebilmesi gösterilmiştir" ${ }^{49}$. Kanımızca Yargıtay’ın görüşü “icra memurlarının İcra ve İflas Kanunu'nu birinci derecede uygulamakla görevli olduğu ilkesi”ne aykırıdı5 ${ }^{50}$. Gerçekten de bir malın haczedilmezlik niteliğine sahip olup olmadığı hususu öncelikle icra müdürü tarafından takdir edilecek, bu konudaki takdir yetkisini yerinde kullanıp kullanmadığı ise şikâyet yolu ile başvurulan icra mahkemesi tarafindan denetlenecektir ${ }^{51}$. Bunun yanı sıra Yargıtay'ın bu görüşünün pratik ihtiyaçlara ne derecede cevap verdiği de tartışmaya açıktır. Çünkü evinin haczedilmesini önlemek isteyen takip borçlusunun daha haciz konmadan evini bir başkasına devretmesi de mümkündür. Haciz işlemi ancak takip kesinleştikten sonra gerçekleşeceğine göre o ana kadar takip borçlusunun durumdan haberdar olması kuvvetle muhtemeldir ve kendi malvarlığı durumunu daha doğrusu borcu ödeyebilecek durumda olup olmadığını en iyi bilebilecek durumda olan borçlunun takibin başlamasından sonra da evini bir başkasına devretmesi mümkündür. $\mathrm{O}$

48 “...IIK.nun 85. maddesine göre haciz isteminin icra memurunca yerine getirilmesi zorunlu olup, memurun haczedilecek menkul, gayrimenkul yada hakların niteliği esas

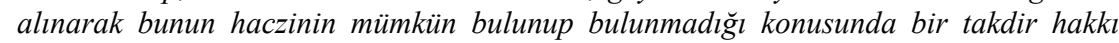
yoktur. Haczedilmezlik durumu, haciz işleminden sonra, borçlunun şikâyeti hâlinde göz önünde bulundurulacağından (HGK.nun 31.03.2004 tarih ve 2004/12-2002 esas2004/196 karar )..." (12. HD 27.6.2006:http://www.hukukturk.com).

${ }^{49}$ Kuru-Makale s. 324-325; Postacioğlu s. 344-345.

${ }^{50}$ Ayn1 yönde: Dönmez s. 10.

${ }^{51}$ Seda Özmumcu, İcra ve İflas Müdürlerinin Takdir Hakkı (Turgut Akıntürk’e Armağan, İstanbul 2008, s. 488-514), s. 504. 
bakımdan böyle bir uygulamanın alacaklının korunması açısından iddia edildiği gibi fonksiyonel olmadığ 1 kanısındayız ${ }^{52}$.

\section{HACZEDILMEZLIK IDDIASININ İCRA MAHKEMESIN- DE İNCELENMESİ USULÜ}

Evin haczedilmezliği iddiasının haklı olup olmadığı mahkeme tarafından keşif ve bilirkişi delillerine başvurulmak suretiyle karara bağlanır ${ }^{53}$. Öncelikle bilirkişi tarafından şikâyete konu taşınmazın müştemilatı ve arsası ile birlikte değeri tespit edilir. Daha sonra borçlunun hâline uygun bir evi ne kadar paraya alabileceği belirlenir ${ }^{54}$. Bunun sonucunda borçlunun ailesi ile birlikte barınması için zorunlu olan hâline münasip evi temin etmesi için gerekli bedel, haczedilen yerin değerinden daha az ise taşınmazın satılmasına karar verilir ve satış bedelinden borçlunun hâline münasip ev alabileceği miktar borçluya bırakı1ır ${ }^{55}$, kalanı alacaklıya ödenir. Bunun yanı sıra mahkemenin satışın, borçlunun hâline münasip ev alabileceği miktardan daha aşağıya yapılmamasını da hüküm altına alması gerektiği kabul edilmektedir ${ }^{56}$. Yaptırılacak bilirkişi incelemesi sonucunda borçlunun durumuna uygun bir ev alabilmesi için gerekli para ile haczedilen evin değeri arasında çok az fark bulunması durumunda şikâyetin kabulüne ve haczin kaldırılmasına karar verilmesi gerekir ${ }^{57}$. Taşınmazların kural olarak ikinci

52 Şayet borçlu yaklaşan haciz ihtimalini hesaba katarak evini bir başkasına devretmişse bu durumda alacaklı bu işleme karşı iptal davası açabilecektir.

${ }^{53}$ Taspinar-Tez s. 176.

${ }^{54}$ Bunun net bir meblağı olarak belirlenmesi gerekir: “...(B)orçlunun hâline münasip evin ise 30-40 milyar TL civarında alınabileceğinin belirtildiği görülmüştür...30-40 milyar civarında biçimde kesin görüs ifade etmeyen bir rakam belirtilerek ulaşılan sonuca göre karar verilmesi doğru görülmediği gibi..." (12. HD 11.03.2005, 2005/1968, 2005/5142: http://www.hukukturk.com).

${ }^{55} \mathrm{Bu}$ durumda borçluya ev alabilmesi için ayrılan bedel bir başka alacaklısı tarafindan haczedilemez. Örnek bir Yargıtay kararı için bkz. İID 3.11.1939 (Sabri Şakir Ansay, Hukuk İcra ve İflâs Usulleri, Ankara 1956, s. 108 dn. 156).

${ }^{56}$ Oskay / Koçak / Deynekli / Doğan s. 2344.

57 “....Borçlunun hâliyle mütenasip bir evi 145 bin liraya alacağı bilirkişice beyan edilmiş, mahcuzun değeri 150 bin lira bulunmuştur. Arada pek az bir fark bulunduğu ve kati bir alış bedeli tayin edilemeyeceği cihetle haczedilmezlik şikâyetinin kabulüne karar verilmek gerektiği düşünülmeden taşınmazın satılmasına ve satış bedelinden 145 bin 
artırmada satılabildiği dikkate alındığında taşınmazın satış bedelinin tahmini değerin \% 40'ını ve satış ve paylaştırma giderlerini karşılaması gerekir (İ̈K m. 129, II). İşte bu bedel üzerinden borçlunun hâline münasip ev alabilmesi için tahmin edilen bir meblağ ayrilacaktır. Görüldüğ̈̈ gibi bu durumda meskenin satılabilme ve alacaklının aradaki fark ile tatmin edilebilme imkânı azalmaktadır ${ }^{58}$.

\section{EVIN HACDEZILMEZLİĞİ İDDİASININ NE ZAMANA KADAR İLERİ SÜRÜLEBILECEĞİ}

538 sayılı Kanun ile ${ }^{59}$ yapılan değişiklikten önce ev hacizlerine özgü olmak üzere "mesken hacizlerinde ihale tarihine kadar şikâyet caizdir" hükmü vardı. Fakat borçlunun şikâyetini son dakikaya kadar geciktirmek yoluyla bu hükmü kötüye kullanıldığ 1 gerekçesiyle bu hüküm kaldırılmıştır. Diğer haczedilmezlik durumlarından farklı olarak ev hacizlerinde şikâyet süresinin uzatılması için bir neden olmadığı sonucuna varılmıştır ${ }^{60}$.

538 sayılı Kanun ile yapılan değişiklikten sonra evin haczedilmezlik iddiasının borçlu tarafından haczin öğrenilmesinden itibaren yedi gün içinde ileri sürülebileceği ve borçlunun yedi gün içinde haczedilmezlik iddiasını ileri sürmezse haczedilmezlik iddiasından vazgeçmiş sayılacağı kabul edilmektedir ${ }^{61}$. Kanımızca bu düzenlemenin arkasında kamu

liranın borçluya tefrikine karar verilmesi isabetsizdir..." (12.HD 29.06.1976, 6320/8084: Senai Olgaç, İcra-İflas, C. 1-2, Ankara 1978, s. 783).

${ }^{58}$ Taşpınar-Tez s. 182.

${ }^{59}$ RG. 6.3.1965, S. 11946.

${ }^{60}$ Kuru-Makale s. 325; Taşpınar-Tez s. 189-190.

${ }^{61}$ Muşul s. 517; Kuru-El Kitabı s. 448. Yargıtay da aynı görüştedir: “...Alacaklı vekili tarafindan ibraz edilen borçlu vekilinin 02.10.2003 tarihli ve 01.12.2003 tarihli imzalı dilekçe içeriğine göre borçlu taraf en geç bu tarihler itibart ile hacizden haberdar olduğunun kabulü gerekir. IIIK'nun 82/12. maddesine dayalı haczedilmezlik itirazı yasal 7 günlük süreye tâbi olduğundan, şikâyetin yasal sürede yapılmadı̆̆ından reddine karar verilmesi gerekirken işin esasının incelenmesi isabetsiz olduğu gibi bilirkişi raporunda taşınmazın değeri 60 milyar TL olarak belirlenmesi karşısında bu değere itibar edilmeyerek mahkemece 40 milyar TL üzerinden taşınmazın satılması her zaman mümkün olmadığı belirtilerek hukukî olmayan gerekçe ile hüküm kurulması da isabetsizdir..." (12. HD 22.4.2005, 5078/8749: Uyar-V s. 7250). Ancak Yargitay'ın 538 sayılı Kanun'un kabulünden önce evin haczedilmezliğine ilişkin şikâyetin süresiz 
düzeninin temini düşüncesi yattığından şikâyet bir süreye tâbi değildir ${ }^{62}$. Diğer deyişle burada süresiz şikâyet hâli vardır. Zira borçluyu fevkalade zor duruma düşüreceği düşüncesiyle tamamıyla haciz dışı tutulmuş malların -borçlunun kendi iradesi dışında- her ne sebeple olursa olsun haczedilememesi gerekir. Bu bakımdan tamamıla haciz dışı tutulması gereken hâline münasip evi haczedilen takip borçlusu herhangi bir süreye bağlı olmaksızın şikâyet yoluna başvurabilitr ${ }^{63}$. Borçlu bakımından doğuracağı ağır sonuçlar dikkate alındığında yedi gün gibi oldukça kısa sayılacak bir sürenin geçmiş olması nedeniyle borçlunun hâline münasip evinin haczedilmezliğinden zımnen vazgeçmiş olduğunun kabulü imkânsızdır.

\section{EV HACIZLERINDE İKAME İLKESININ UYGULANIP UYGULANAMAYACAĞI}

Kanun borçlunun ihtiyacından büyük olan evi yerine borçlu için lüzumlu ve yeterli bir ev alabilecek kadar paranın borçluya bırakılması şartıyla o evin haczine cevaz vermektedir. Öğretide ikame ilkesi olarak adlandırılan bu ilkenin diğer mal hacizlerinde de uygulanmasının uygun olacağ1 kabul edilmektedir ${ }^{64}$. Örneğin çok kıymetli bir sofra takımı haczedilerek bunun satılmasından elde edilecek bedelden borçluya normal nitelikte bir sofra takımı alabilecek kadar paranın bırakılması ve artanın alacaklıya verilmesi mümkün olmalıdır. Buna alacaklının borçlunun değerli bir malının normal nitelikte bir mal ile değiştirilebilmesini isteyebilme hakkı denebilir ${ }^{65}$. Bu ilke İsviçre Federal Mahkemesi'nin yerleşmiş içtihatları ile bütün haczedilmezlik durumları için kabul edilmiştir ${ }^{66}$. Buna göre borçlunun değerli bir eşyasının haczini

olduğu yönünde de kararlar verdiği belirtilmiştir (Kemal Arar, İcra ve İflas Hükümleri, Ankara 1944, s. 190-191).

${ }^{62}$ Yargitay da eski tarihli bir kararında kanunen haczi kabil olmayan malların haczi hâlinde şikâyetin süreye bağlı olmadığından hareketle şikâyetin süre yönünden reddolunmasının isabetsiz olduğu sonucuna varmıştır (12. HD 6.4.1976, 1697/4254: Hakan Pekcanıtez, İcra-İflâs Hukukunda Şikâyet, Ankara 1986, s. 88 dn. 96).

${ }^{63}$ Karş. Refik Korkusuz, İcra Hukuku ve Uygulaması, Ankara 2004, s. 234.

${ }^{64}$ Ansay s. 98; Belgesay s. 180; Kuru-Makale s. 313.

${ }^{65}$ Kuru-Makale s. 313.

${ }^{66}$ Belgesay s. 180; Taşpınar-Tez s. 176. 
isteyen alacaklının, borçluya aynı ihtiyacını karşılayacak daha değersiz bir şeyi teslim etmesi gerekmektedir. Alacaklı, haczedilen şey yerine borçluya verdiği eşyanın bedelini de satış bedelinden icra masrafi olarak tahsil edebilir. Öğretide Kuru, herhangi bir ayrım yapmaksızın ev hacizlerinde de ikame ilkesinin uygulandığını ifade etmiştir ${ }^{67}$. Postacıoğlu ${ }^{68}$ ise ev hacizlerinde ikame ilkesinin uygulanması konusunda İsviçre Federal Mahkeme içtihatlarından ayrıldığımızı ve bunun amaca daha uygun olduğunu dile getirmiştir. Yazara göre gerekli eşyanın alacaklı tarafından karşılanması çoğu zaman yüksek bir masrafı gerektirmediğinden mümkün ise de aynı şeyin ev haczi bakımından söylenmesi güç olduğundan Türk kanun koyucusu tarafindan evin seçiminin de takip borçlusuna bırakılması suretiyle sadece ailevi ve sosyal durumuna uygun düşen, alabileceği bir ev bedelinin kendisine satış bedelinden ayrılması benimsenmiştir. $\mathrm{O}$ halde borçluya belirli bir evin verilmesi koşuluyla ona ait evin haczedilip, paraya çevrilmesi ve elde edilecek paranın tamamının alacaklıya ödenmesi kabul edilemez ${ }^{69}$.

Yargıtay bir kararında, borçluya, bilirkişinin takdir ettiği meblağdan daha ucuza bir ev vermek ve bilirkişinin takdir ettiği bedelden daha fazlasını almak için alacaklının yaptığ teklifi reddetmiştir $^{70}$. Belgesay, bu kararı eleştirmiş ve gerekli zorunlu eşyada olduğu gibi burada da ikame ilkesinin uygulanması gerektiğini, alacaklının borçlunun durumuna uygun evi için tapuyu verdikten sonra evin haczedileceğini, sonra bunun için ödediği parayı satış bedelinden alacağı ile birlikte tahsil edeceğini savunmuştur $^{71}$. Bu görüş eleştirilmiş ve İIK $\mathrm{m}$. 82, I/12'i hükmünün açıklığı karşısında bu düşünceye katılmanın olanaklı olmadığı haklı olarak ifade edilmiştir ${ }^{72}$. Gerçekten de bahsi geçen hüküm açıkça evin kıymetinin fazla olması durumunda borçlunun hâline münasip bir ev

\footnotetext{
${ }^{67}$ Kuru-Makale s. 313.

${ }^{68}$ Postacioğlu s. 362.

${ }^{69}$ Postacioğlu s. 362.

70 İiD 2.12.1937 36/48 (Belgesay s. 188).

${ }^{71}$ Belgesay s. 188.

72 Taşpınar s. 177.
} 
alabilmesi için gerekli meblağ ayrılmak şartıyla evin haczedilerek satılacağını emretmektedir.

\section{EV ÜZERINE IPOTEK KONULMASININ HACZEDIL- MEZLİ̆E ETKISİ}

İIKK m. 83/a uyarınca 82 ve 83 üncü maddelerde yazılı mal ve hakların haczolunabileceğine dair önceden yapılan anlaşmalar muteber değildir ${ }^{73}$. Haczedilmezlikten feragat konusunda tarafların anlaşması mümkün olmadığ 1 gibi borçlunun bu konuda önceden feragatte bulunması da geçerli değildir ${ }^{74}$. Borçlu haciz yapılıncaya kadar muvafakatini tek taraflı olarak geri alabiliir ${ }^{75}$. Takip borçlusunun hâline münasip evin haczedilmezlik sıfatından feragat edip edemeyeceği özelilikle takip borçlusunun evini ipotek ettirmesi durumunda gündeme gelmektedir. Bu konuda Yargıtay ile öğretinin görüşleri arasında önemli farklılıklar bulunmaktadır.

\section{A. YARGITAY'IN GÖRÜŞÜ}

Yargitay'in bu konudaki tutumu zamana göre farklılık göstermiştir. Yargıtay verdiği eski tarihli kararlarında evin bir borçtan dolayı ipotek edilmesi hâlinde haczedilmezliğin ileri sürülebileceğini kabul etmekteydi. Örneğin: “...Haciz olunan evin başka bir alacaktan dolayı ipotekli olması

\footnotetext{
73 “...Haciz işleminden önce, borçlunun hacze izin vereceğine iliş̧kin açılklaması, kabul edilebilir bir iradenin ürünü olamaz. Bu çeşit açıklama ancak haciz sirasından veya sonraki dönemde meydana çıkarsa, hukukî sonuç doğuracaktır...” (12. HD 11.10.1988, 1987/13349-11239: Ceylan s. 57 dn. 22).

74 Borçlunun hâline münasip evinin haczedilmezliğinden iflastan önce feragat edip edemeyeceği konusunda iki farklı görüş ileri sürülmüştür. Bir görüşe göre iflastan önce borçluya ait ev alacaklılar tarafından haczedilmiş ve borçlu bu malın haczedilmezlik sıfatından açıkça veya süresi içerisinde şikâyette bulunmayarak zımnen feragat etmiş ise mahcuz evin iflas masasına geçmesinden sonra müflis bu evi hakkında haczedilmezlik iddiasında bulunamaz. Bu görüş için bkz. Kuru-III s. 2854; Kuru / Arslan / Yılmaz s. 507; Dönmez s. 161. Bizim de katıldığımız diğer görüşe göre ise daha önce haczedilmezlik iddiasında bulunulmamasına karşın mahcuz evin daha sonra iflas masasına geçmesi durumunda haczedilmezlik iddiası ileri sürülebilecektir. Bkz. Necmeddin Berkin, İflas Hukuku, İstanbul 1972, s. 206.

${ }^{75}$ Berkin-Makale s. 114.
} 
takip olunan alacağın istifasını temin için yapılan haciz sebebiyle haczedilmezlik iddiasının tetkikine mani teşkil etmez..."76.

Daha sonra görüş değiş̧iren Yargıtay'a göre bir alacaklısı lehine evi üzerinde ipotek tesis eden borçlu bununla diğer bütün alacaklılarına karşı haczedilmezlik iddiasından feragat etmiş olur $^{77}$. Bu görüşe göre borçlunun bir alacaklısı lehine evi üzerinde ipotek tesis etmesi onun eve ihtiyacı olmadığını kabul etmesi anlamına gelir ${ }^{78}$.

Bununla birlikte Yargıtay bu görüşüne kimi istisnalar da tanımıştır. Yargıtay'ın tanıdığ 1 birinci istisnaya göre takip borçlusu, satıcıdan aldığ 1 evin satış bedelinin bakiyesini temin için satıcı lehine evi üzerinde ipotek tesis etmişse, bu halde diğer alacaklılarına karşı da haczedilmezlik iddiasından feragat etmiş sayılmaz ${ }^{79}$. Yargıtay'ın tanıdığı ikinci istisna ise ev (konut) kredisine ilişkindir. Buna göre takip borçlusu ev kredisi almak için kredi veren kurum veya kişiye evini ipotek etmiş ise bununla diğer alacaklılarına karşı da haczedilmezlik iddiasından feragat etmiş sayılmaz ${ }^{80}$. Yargıtay'ın tanıdığ 1 bir başka istisna ise takip borçlusunun zirai kredi almak için evini ipotek ettirmiş olmasıdır. Yargıtay’a göre bu durumdaki takip borçlusu diğer alacaklılara karşı da haczedilmezlik iddiasından feragat etmiş sayılmaz ${ }^{81}$. Yargıtay tanımış olduğu bu istisnai

${ }^{76}$ İiD 13.1.1942 (Belgesay s. 187); İiD 3.1.1953, 21/5671 (Taşpınar-Tez s. 182).

77 “...(Borçlu) taşınmazı teminat olarak göstererek bankadan ticari kredi alıp üzerine ipotek koydurduğundan haczedilmezlik isteminde bulunma olană̆ yoktur...” (12. HD 18.1.2007, 2006/22756-389: Oskay / Koçak / Deynekli / Doğan s. 2375).

78 “...Borçlunun serbest iradesi ile kurduğu ipotekler, adı geçenin daha sonra bu yerle ilgili olarak meskeniyet iddiasında bulunmasını engeller. Zira, evini kendi iradesiyle ipotek eden borçlunun artık ona ihtiyacı olmadı̆̆ kabul edilmelidir..." (12. HD 5.7.2004, 13741/17768: Gönen Eriş, İcra ve İflas Kanunu, Ankara 2005, s. 489).

79 12. HD 24.9.1979, 7434/7177 (Talih Uyar, İcra Hukukunda Haciz, 2. B., Manisa 1990, s. 668).

80 “...Şikâyetçi, alacaklı bankadan almış bulunduğu konut kredisi nedeniyle, taşınmazı üzerine onun lehine ipotek konulduğunu ileri sürmüştür. Söz konusu bu durumun varlığ hâlinde haczedilmezlik şikâyetinin dinlenme olanağ bulunmaktadır. Sözü edilen bu hususun yöntemince araştırllıp sonuçlandırlmadan yazll şekilde şikâyetin reddine karar verilmesi isabetsizdir...” (12.HD 9.7.2008, 12307/14721: Dönmez s. 169).

81 “...Öncelikle belirtelim ki; borçlunun devam arz etmeyen her sene mutad olarak tarla icarından geliri olduğunun kabulü kendi taşınmazı ile ilgili haczedilmezlik şikâyetini ileri sürmesine engel değildir. Zira 1934 doğumlu olan borçlunun kendi tarlası dışında 
hâllerde takip borçlusunun evi üzerinde ipotek tesis ettirmiş olması durumunda bunun haczedilmezlik iddiasından feragat sayılıp sayılmayacağının ortaya konulabilmesi için yerel mahkemelerin ipoteğin niteliğini araştırmaları gerektiğini vurgulamaktadır ${ }^{82}$.

Buna karşılık haciz tarihinde ipotek konusu olan borcun ödenmiş olması hâlinde, ipotekle yükümlü bulunmayan taşınmaz hakkında haczedilmezlik şikâyetinde bulunulabilir. Keza, ipotek borcunun ödenmiş olmasına rağmen taşınmazın tapu kaydında ipoteğin mevcut olması haczedilmezlik şikâyetini engellemez ${ }^{83}$. Önemli olan ipotek borcunun haciz tarihinden evvel ödenip ödenmediğidir ${ }^{84}$.

İpoteğin muris tarafindan konulması durumunda mirasçıların alacaklılarının bu taşınmaza haciz koyduramayacakları zira miras

icarla geçimini sürekli olarak temin edebileceğinin kabulü yerinde olmadı̆̆ gibi; haczedilmezlik şikâyetinin konusunu teşkil eden borçlu adına kayıtlı taşınmazlardan yıllık 1608,00.- YTL. ile ( 2 ) kişilik bir ailenin zaruri ihtiyaçlarını dahi karşılaması mümkün değildir. Öte yandan, taşınmazların Ziraat Bankası'na ipotekli olduğu bu ipoteğin zirai kredi almak için kurulan zorunlu ipoteklerden olup olmadiğ da yöntemince araştırılmaksızın..." (12. HD 26.2.2007, 878/3313: http://www.hukukturk.com).

82 “...Somut olayda haczedilmezliğe konu taşınmaz üzerinde TC. Ziraat Bankası lehine ipotek bulunduğu görüldüğ̈̈nden, mahkemece bu ipoteğin niteliği araştırılarak açıklanan koşullar doğrultusunda meskeniyet şikâyetinin değerlendirilmesi gerekirken...” (12. HD 2.2.2007, 2006/23816-1791: Oskay / Koçak / Deynekli / Doğan s. 2369).

83 “....Haciz tarihinde ipotek konusu borcun ödenmiş olması hâlinde, ipotekle yükümlü bulunmayan taşınmaz hakkında meskeniyet şikâyetinde bulunulabilir. Aksi takdirde, kurulan bir ipotek borcu ödenmiş olsa dahi bundan sonraki tüm hacizler yönünden meskeniyet şikâyetinin mümkün bulunmadı̆̆ gibi kabul edilemeyecek bir sonuç ortaya çıkar..." (12. HD 20.5.2003, 8421/11468: Oskay / Koçak / Deynekli / Doğan s. 2458).

84 “.... Somut olayda, taşınmaz kaydına 04.04.2005 tarihinde haciz uygulanmış olduğu ve bu tarihte borçlu hisse üzerinde E. Bankası lehine 13.05.1987 tarihli, (R) lehine 09.05.1991 tarihli ipoteklerin mevcut olduğu görülmektedir. Alacakl vekili 06.10.2005 havale tarihli dilekçesinde davacının hissesi üzerine bulunan ipoteklerin meskeniyet iddiası ile çeliştiğinden iddianın geçersiz kalacağını savunmuştur. Karar gerekçesinde, ipoteklerin varlı̆̆ kabul edildiği hâlde mahiyetleri incelenip tartışılmamıştır. O hâlde, mahkemece E. Bankası'na verilen ipoteğin tapudan mahiyeti belirlenip zorunlu ipotek olup olmadiğ tespit edilmeli, (R) lehine verilen ipoteğin ise haciz tarihinden önce kalkıp kalmadı̆̆ yöntemince araştırılıp sonucuna göre karar verilmelidir..." (12. HD 20.10.2006, 16490/19767: Oskay / Koçak / Deynekli / Doğan s. 2387). 
bırakanın ipotek nedeniyle evin haczedilmezliği iddiasından vazgeçmesinin mirasçıları etkilemeyeceği kabul edilmektedir ${ }^{85}$. Örneğin: “...Murisin să̆lı̆̆ında meskeniyet hakkından feragat etmiş olması mirasçılarına şamil değildir..." meskeniyet iddiasından feragat edişinin mirasçıların şahıslarına bağll haklart etkiyemeyeceği gözetilmeden şikâyetin reddi isabetsizdir..." ${ }^{, 7}$. Kanımızca böyle durumlarda mirasçıların haczedilmezliği peşinen ileri sürüp süremeyecekleri söylenemez. Şayet onlara intikal eden ev, mirasçılar açısından "hâline münasip ev" olarak nitelendirilebiliyorsa mirasçılar haczedilmezliği ileri sürebilirler. Aksi takdirde ileri sürememeleri gerekir.

\section{B. ÖĞRETININ GÖRÜŞÜ}

Haczedilmezlik iddiasından haciz ${ }^{88}$ tarihinden önceki bir dönemde yapılan feragat geçersizdir. $\mathrm{Bu}$ konuda taraflar arasında yapılan anlaşmalar da geçerli değildir (İ̈K m. 83/a). Bundan başka evini ipotek eden borçlunun haczedilmezlik iddiasından feragat ettiği kabul edilse dahi bu feragat sadece ipotek alacaklısına karşıdır. Çünkü borçlunun belirli bir alacaklıya karşı evinin haczedilmezlik niteliğinden vazgeçmesi sadece o alacaklıya karşı hüküm ifade eder. Dolayısıyla borçlu, evini haczettirmek isteyen diğer alacaklılara karşı haczedilmezlik iddiasında bulunabilir $^{89}$. Kanımızca hakim görüşün dayandığg gerekçeler isabetlidir.

${ }^{85}$ Kuru-Makale s. 323; Üstündağ s. 188 dn. 575; Dönmez s. 162.

${ }^{86}$ İ̈ 24.2.1940 (Dönmez s. 163).

${ }^{87}$ İID 14.9.1972, 8066/8146 (Hasan Özkan, İcra ve İflâs Davaları Tatbikatı, Ankara 1999, s. 580).

${ }^{88}$ Buradaki haciz ile kastedilen kesin hacizdir. İhtiyati haciz sırasında borçlunun meskeninin haczedilmesinden feragat etmesi geçerli değildir. Çünkü ihtiyati haciz kesin haciz değildir (Kuru-El Kitabı s. 446; Yalçın s. 61).

${ }^{89}$ Ansay s. 109; Kuru-Makale s. 315; Kuru-I s. 813; Kuru-El Kitabı s. 448; Üstündağ s. 189; Postacıoğlu s. 336; Muşul s. 519; Yıldırım / Deren-Yıldırım s. 155; Kuru / Arslan / Yılmaz s. 273; İbrahim Aşık, İcra Sözleşmeleri, Ankara 2006, s. 126-127. Aksi görüşte olan Arslan'a göre borçlu, haczedilmez bir malını rehnetmek suretiyle haczedilmezlik imtiyazından feragat etmiş olmaktadır. Diğer deyişle, haczedilmezliği sadece o rehnin alacaklısına karşı değil, bir başka alacaklıya karşı da ileri sürememelidir (Ramazan Arslan, Alacakların Tahsili Hususunda Cebri İcra ve Yargılama Anında Karşılaşılan Sorunlar ve Çözüm Yolları (Alacakların Tahsili Hususunda Cebri İcra ve Yargılama 
Borçlunun evini ipotek etmesi durumunda bunun tüm alacaklılarına karşı haczedilmezlikten feragat ettiği şeklinde yorumlanması borçlunun (ve ailesinin) öngörülmesi çok güç bir riskle karşı karşıya bırakılması anlamına gelecektir. $\mathrm{O}$ nedenle borçlunun bir alacaklısına karşı evini ipotek etmesi dar yorumlanmalı ve sadece ona karşı haczedilmezlik iddiasından feragat ettiği sonucuna varılmalıdır.

\section{TAKIPP BORÇLUSU DIŞINDA ÜÇÜNCÜ KIŞSiLER EVIN HACZEDILMEZLIĞİiNI İDDIA EDEBILLIR MI?}

Öğretide borçlunun haczedilmezlik niteliğinden feragat etmesinin aile fertlerini bağlamayacağı hükmün koruma amacına göre onların da şikâyet hakkına sahip olduklarının kabul edildiği durumlarda feragate rağmen haczedilmezlik iddiasını ileri sürebilecekleri kabul edilmektedir ${ }^{90}$. Gerçekten de AY m. 41, I'de ailenin Türk toplumunun temeli olduğu vurgulanmıştır. Keza, Türkiye'nin de taraf olduğu İnsan Hakları Evrensel Beyannamesi'nin 16. maddesinin üçüncü fikrasında da ailenin toplumun doğal ve temel unsuru olduğu ve toplum ve devlet tarafından korunacağı ifade edilmiştir. Bu hükümler dikkate alındığında devletin aile kurumunun korunması konusunda önemli bir görevi üstlenmiş olduğu açıkça anlaşılmaktadır. Bunun yanı sıra icra takibi prosedürü içinde sadece alacaklı ya da alacaklılar ve borçlunun menfaatlerinin korunması değil, üçüncü kişilerin de menfaatlerinin korunması söz konusu olabilir ${ }^{91}$. Bu bakımdan ilgili üçüncü kişilerin de şikâyet yoluna başvurabilmesini doğal karşılamak gerekir. Nitekim İsviçre Federal Mahkemesi de borçlunun haczi caiz olmayan eşya ve alacaklarının haczine rıza göstermesinin aile fertlerinin haciz işlemine karş1 şikâyette bulunma haklarını düşürmeyeceğini kabul etmiştir ${ }^{92}$. İsviçre Federal Mahkemesi bir başka kararında da şikayet neticesinde

Aşamasında Karşılaşılan Sorunlar ve Çözüm Yolları, 5-7 Temmuz 1991, Abant Palace, s. 7-24), s. 17).

${ }^{90}$ Evren Kılıçoğlu, İcra Sözleşmeleri, İstanbul 2005, s. 133; Yıldırım / Deren-Yıldırım s. 154; Dönmez s. 162. Karş. Pekcanıtez / Atalay / Sungurtekin / Özekes s. 245; Yıldırım /

Deren-Yıldırım s. 145.

${ }^{91}$ Sungurtekin Özkan s. 188.

${ }^{92}$ Berkin-Makale s. 115. 
fiilen müşkül duruma düşmüş olan kimselerin şikayet yoluna başvurabileceklerini dile getirmiştir ${ }^{93}$. Yargıtay ise şikâyet hakkının yegâne sahibi olarak takip borçlusunu görmektedir ${ }^{94}$.

Buna karşıllk borçlu tarafindan üçüncü kişiye satılan taşınmazın satış işlemi hakkında tasarrufun iptaline karar verilmesi hâlinde, icra takibinde borçlu sıfatı olmayan davalı üçüncü kişinin evin haczedilmezliği şikâyetinde bulunması mümkün müdür? Bu soruya gerek öğretide ${ }^{95}$ gerekse yarg1 kararlarında olumsuz cevap verilmektedir. Ancak Yargıtay görüşünü dayandırdığı gerekçeleri zamanla değiştirmiştir. Yargıtay eski kararlarında takip borçlusunun bu durumda haczedilmezlik iddiasında bulunamamasını kötüniyetin hukuken korunmamasına bağlamıştır. Örneğin : “...Dava İIK’nun 277 ve devamı maddelerine dayalı tasarrufun iptali istemine ilişkindir. Mahkemece, dava, davalı (borçlu) M. Y. Tarafindan diğer davalı üçüncü kişi D.M. üzerine kayden geçirilen avlulu kerpiç ev ve samanlı vasfindaki taşınmazın, İIK. 'nun 82/12. maddesine göre haczi caiz olmayan ve borçlunun hâline münasip meskenden saylan taşınmazlardan bulunduğundan bahisle reddolunmuştur. IIK'nun 82/12 maddesi, borçlunun ve ailesinin insanca yaşamasl, ekonomik varlığını devam ettirebilmesi ve barınma gereksinimini karşılaması amacıyla getirilmiş olup borçlunun aksine davranışları yasaca korunmaya değer görülmemiştir. Borçlu M.Y. taşınmazda malik bulunduğu 1 / 2 payın tamamını çok düşük bir bedelle diğer davalıya kayden geçirmiş olmakla, tüm alacaklılarına karşı taşınmazı üzerindeki haczedilmezlik (meskeniyet) iddiasindan önceden ve zımnen vazgeçmiş sayılır. Bu durumda davanın kabulü gerekirken, yazılı

\footnotetext{
${ }^{93}$ BGE 99 III 58, 105 III 104 (Kiraz s. 563).

94 “...IIK'nun 82/12. maddesinden faydalanma hakkı sadece icra takip borçlusuna ait bulunmaktadır. Somut olayda şikâyetçinin lehine taşınmaz üzerine aile konutu şerhi verilmiş bulunması durumu takipte taraf olmayan şikâyetçinin bu hakka dayanarak haczedilmezlik şikâyetinde bulunmasına, IIIK'nun 82/12. maddesi imkân tanımamaktadır..." (12. HD 25.4.2006, 5829/8852: Pekcanitez / Atalay / Sungurtekin / Özekes s. 245 dn. 208).

${ }^{95}$ Oskay / Koçak / Deynekli / Doğan s. 2345.
} 
şekilde reddine karar verilmesi usul ve yasaya aykır olup bozmayı gerektirmiştir..." $"$.

Yeni tarihli bir kararında ise daha isabetli olarak "...Alacakl tarafindan borçlu hakkında yapılan icra takibinde, alacaklı Kadıköy 5. A. Hukuk Mahkemesi 'nde tasarrufun iptali davası açmış ve 46 parsel 7 nolu dairenin satışına ilişkin tasarrufun iptaline karar verilmesi sonucunda anılan ilama dayalı olarak 3. kişi adına tapuda kayıtlı taşınmaz üzerine haciz konulmuş, borçlu meskeniyet iddiasina dayalı olarak haczedilmezlik şikâyetinde bulunmuştur. IIIK 'nun 283/1. maddesine göre "davact, iptal davası sabit olduğu takdirde, bu davaya konu teşkil eden mal üzerinde cebri icra yolu ile, hakkını almak yetkisini elde eder ve davanın konusu taşınmazsa, davalı üçüncü şahıs üzerindeki kaydın tashihine mahal olmadan o taşınmazın haciz ve satışını isteyebilir. Satış ile 3. kişiye geçen mülkiyet tasarrufun iptaline karar verilmesi ile borçluya geri dönmez. Yalnızca, alacakliya, 3. kişiye ait taşınmaz üzerine haciz koydurarak sattırmak suretiyle alacağını tahsil imkânı verir. Hacze dayanak yapılan tasarrufun iptali ilamında da anılan yasa hükmüne uygun olarak yalnızca satış işleminin iptaline karar verilmekle yetinilmiş olup 3. kişi adına olan tapu kaydının iptali ile borçlu adına tesciline dair bir hüküm kurulmamıştır. Bu nedenle taşınmazın mülkiyeti 3. kişiye ait olup, borçlunun kendisine ait olmayan taşınmaz üzerine konulan haciz nedeniyle IIK 'nun 82/12. maddesine dayall olarak haczedilmezlik şikâyetinde bulunması mümkün olmadı̆̆ı gibi şikâyette de hukukî yararı yoktur..." sonucuna varmıştır. Ancak kanımızca böyle bir durumda her ne kadar borçlu haczedilmezlik iddiasında bulunamayacak ise de şayet tasarrufun iptali davasına konu olan ev, yeni malik açısından "hâline münasip" ise onun haczedilmezlik iddiasında bulunabilmesi gerekir ${ }^{97}$. Bu

\footnotetext{
96 15. HD 27.2.1995 706/1077 (Dönmez s. 128-129)

97 Yargıtay ise aksi görüştedir: "...Alacaklı tarafindan borçlu hakkındaa yapılan icra takibinde, alacakl Actpayam Asliye Hukuk Mahkemesinde tasarrufun iptali davast açmış ve 7463 parselde kayıtll taşıımazın satışına ilişkin tasarrufun iptaline karar verilmesi sonucunda anılan ilama dayalı olarak 3. kişi adına tapuda kayıtlı taşınmaz üzerine haciz konulmuş, borçlu ve taşınmaz maliki üçüncü şahıs meskeniyet iddiasına dayalı olarak haczedilmezlik şikâyetinde bulunmuşlardır. Şikâyetin yasal dayanağı olan, IIKK.nun 82/12. maddesi uyarınca "borçlunun hâline münasip evinin
} 
durumda evin değeri fazla ise satılıp yeni malike kendi hâline uygun düşen bir ev alabilmesi için gerekli miktar bırakılacak ve bakiye bedel takip alacaklısına ödenecektir. Burada yeni malikin takibin tarafı olmadığ1 söylenerek bu görüşe itiraz edilebilirse de haczedilmezlik şikâyeti sadece takip borçlusu tarafindan ileri sürülmemektedir. Yukarıda görüldüğü gibi bu iddiada hukukî menfaati olan aile fertlerinin de haczedilmezlik iddiasında bulunması mümkündür. Bu bakımdan yeni malikin de böyle bir şikâyette bulunmakta hukukî yararı olduğu kanısindayiz.

\section{AIILE KONUTUNUN MESKENIYYET İDDİASINA KONU OLUP OLAMAYACAĞI}

Türk Medeni Kanunu'nun 194. maddesinde düzenlenmiş bulunan aile konutu ile kastedilen eşlerin evlilik birliğinin devamı sırasında ortak yaşamı sürdürmelerinin gerekli kıldığı bir yerde ortak olarak oturma ihtiyacının giderilmesinde kullanılmak üzere sürekli olarak seçtikleri, kısaca aile yaşamlarının merkezi durumuna getirdikleri konut olarak kullanılmaya elverişli taşınır ve taşınmaz yerdir ${ }^{98}$.

Belirtmek gerekir ki, "aile konutu" ile "borçlunun hâline münasip evi" kavramları her zaman örtüşmez. Diğer deyişle, her aile konutu aynı zamanda borçlunun hâline münasip evi olmak zorunda değildir. Tersi de doğrudur. Bu bağlamda, bir yazlık ev duruma göre borçlunun hâline münasip evi olarak nitelendirilebilirken ${ }^{99}$ böylesi ikincil nitelikteki konutlar aile konutu sayılmazlar ${ }^{100}$.

haczedilemeyeceğinden" meskeniyet şikâyetinde bulunma hakkı borçluya ait olup, icra takibinde borçlu sifatı olmayan tasarrufun iptali ilamının davalısı 3. kişinin şikâyet hakkl yoktur..." (12. HD 8.2.2005, 2004/24990, 2005/2109: http://www.hukukturk).

${ }^{98}$ Mustafa Dural / Tufan Öğüz / Mustafa Alper Gümüş, Türk Özel Hukuku C. III, Aile Hukuku, İstanbul 2008, s. 160. Karş. Şükran Şıpka, Aile Konutu, İstanbul 2004, s. 77 vd.; Ayhan Uçar, 4721 Sayılı Medeni Kanun ile İhdas Edilen Yeni Bir Müessese: Aile Konutu Müessesi (AÜEHFD 2006/1-2, s. 395-442), s. 398 vd.

99 Örneğin: “...Meskeniyet şikâyetinin dinlenmesi için borçlunun sürekli o evde oturması şart değildir. Yazlık olarak kullanılan ev için de meskeniyet iddiasında bulunulabilir..." (12. HD 4.12.2006, 20155/22861: Oskay / Koçak / Deynekli / Doğan s. 2382).

${ }^{100}$ Alper Gümüş, Türk Medeni Kanunu'nun Getirdiği Yeni Şerhler, 2. B., İstanbul 2007, s. 22. 
Acaba aile konutu aynı zamanda borçlu eş bakımından hâline münasip ev niteliğinde ise borçlu eşin o konutun haczedilmezlik niteliğinden feragat etmesi diğer eşin rızasına bağlı olacak mıdır? Öğretideki bir görüşe göre aynı zamanda hâle münasip ev olan aile konutunun haczedilmesinin mümkün olmadığı haczedilmezlik iddiası ile ileri sürülebilir ve aile konutunun korunması bakımından, haczedilmezlikten feragat için diğer eşin açık rızasının aranması gerektiği akla gelirse de haczedilmezlik niteliği aile konutu niteliğine bağlı bir husus olmadığından, mevcut hukukî durum bakımından TMK m. 194 karşısında İIK m. 82, I/12'nin özel hüküm olup haczedilmezlikten feragat konusunda diğer eşin açık rızasının aranmasına gerek yoktur ${ }^{101}$.

Biz bu görüşe katılamıyoruz. Şöyle ki; TMK m. 194, I uyarınca eşlerden biri diğer eşin açık rızası bulunmadıkça, aile konutu ile ilgili kira sözleşmesini feshedemez, aile konutunu devredemez veya aile konutu üzerindeki hakları sinırlayamaz. Maddede her ne kadar sadece kira sözleşmesinden bahsedilmişse de öğretide kira sözleşmesini sona erdiren ve tahliye tehlikesi yaratacak olan her türlü hukukî işlemin diğer eşin rızasına bağlı olmasının bu normun amacına uygun olacağı kabul edilmektedir ${ }^{102}$. Kanımızca takip borçlusu eşin haczedilmezlikten feragat etmesi de evin tahliyesi tehlikesini doğurabilecek nitelikte olduğundan buraya dâhil edilebilir. Nitekim öğretide TMK m. 194 hükmü ile getirilen sınırlamanın amacından aile konutunun kaybına neden olacak ve ailenin barınma hakkını tehlikeye düşürecek her türlü hukukî işlemin diğer eşin rızasına bağlı olacağı sonucunun çıkarılması gerektiği kabul edilmiştir ${ }^{103}$. Gerçekten de aile konutunun eşler ve çocuklar için manevi ve duygusal önemi vardır. Eşler acı ve tatlı günlerini, mahremiyetlerini, tüm kişisel ve sosyal ilişkilerini bu aile konutunu merkez alarak geçirmişlerdir. Komşularla ilişkiler, sosyal ve kültürel çevre ile bağl1lık, çocukların okul

101 Atalay s. 55-56; İbrahim Özbay, İcra ve İflas Hukukumuzda Haczedilmezlikten Feragat (İ̈K m. 83/a) (AÜEHFD 2005, C. IX, s. 543-567), s. 560; Murat Dönmez, Aile Konutunun Haczi (TBBD 2008/77, s. 349-358), s. 355; Oskay / Koçak / Deynekli / Doğan s. 2346.

${ }^{102}$ Şık s. 133-134.

103 Şipka s. 198. 
ve arkadaş ilişkileri, gelişimleri, bahçe ve sokakta geçen günleri, varsa büyük anne ve büyükbabalarla birlikte geçirilen yıllar, hep aile konutu ile bütünleşen yaşantılardır. Ayrıca aile konutu, kural olarak, eşlerin ve çocukların özel ve resmi haberleşme adresleri, yerleşim yerleridir ${ }^{104}$. TMK m. 194 ile evlilik birliği, çocukların varlığı ve dolayısıyla kamusal yarar korunmaktadır ${ }^{105}$. Dolayısıyla TMK m. 194 ile getirilen sınırlamanın amacından aile konutunun kaybına neden olacak ve ailenin barınma hakkını tehlikeye düşürecek her türlü hukukî işlemin diğer eşin

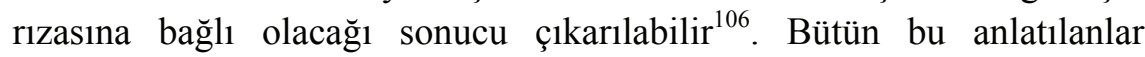
karşısında taşınmaz üzerine aile konutu şerhinin verildiği durumda bu konut aynı zamanda borçlunun hâline münasip evi ise borçlu olmayan eşin de haczedilmezlik şikâyetinde bulunabileceği konusunda tereddüt edilmemelidir. Kanımızca takip borçlusu olan eşin aynı zamanda aile konutu durumunda bulunan hâline münasip evin haczedilmezliğinden diğer eşin rızası olmaksızın feragat etmesi geçerli değildir.

Öğretide, TMK m. 194 uyarınca taşınmazın tapu kaydına aile konutu olarak şerh verilmesinin, aile konutunun tapu sicilindeki maliki olan borçlunun borcundan dolayı alacaklıların yapacakları bir icra takibi sonucu aile konutu olan taşınmazın satışına engel teşkil etmeyeceği savunulmuş ${ }^{107}$; yargı kararlarında da ${ }^{108}$ evin haczedilmezliği iddiasını sadece takip borçlusunun ileri sürebileceği; taşınmaz üzerine aile konutu şerhi verilmiş bulunması durumunda takipte taraf olmayan eşin buna dayanarak haczedilmezlik şikâyetinde bulunamayacağı dile getirilmiştir. Kanımızca bu şekilde yapılan bir genelleme hatalıdır. Şayet tapuya aile konutu olduğu şerh verilmiş bulunan ev aynı zamanda borçlunun hâline

\footnotetext{
${ }^{104}$ Şıpka s. 57.

105 Gümüş s. 19.

${ }^{106}$ Şipka s. 198.

107 Oskay / Koçak / Deynekli / Doğan s. 2346; Özbay s. 560.

108 “... TMK'nun 194. maddesi aynen "Eşlerden biri, diğer eşin açık rızası bulunmadıkça aile konutu ile ilgili kira sözleşmesini feshedeme, aile konutunu devredemez veya aile konutu üzerindeki haklarl sinırlayamaz" hükmünü içermektedir. Yasal bu düzenleme, aile konutunun tapu sicilinde maliki olan borçlunun borcundan dolayı alacaklıların yapacakları bir icra takibi sonucu satışına engel teşkil etmemektedir..." (12. HD 25.4.2006, 5829/8852: Oskay / Koçak / Deynekli / Doğan s. 2404).
} 
münasip ise bu durumda hem takip borçlusu hem de onun aile fertleri haczedilmezlik şikâyetinde bulunabilecektir.

\section{EVİN HACZEDILMEZLİĞİ KURALININ ISTISNASI}

İIK m. 82, II c.1 uyarınca Medeni Kanunu'nun 807. maddesi hükmü saklıdır. Buna göre borçlu, kanunî ipotek hakkı sahiplerine karşı mahcuz malın haczinin caiz olmadığını ileri süremez. 743 sayılı eski Medeni Kanun'un 807. maddesinin yerini 22.11.2001 tarih ve 4721 sayılı Türk Medeni Kanunu'nun 893. maddesi almıştır. Bu maddeye göre aşağıdaki alacaklılar, kanunî ipotek hakkının tescilini isteyebilirler:

1. Satıştan doğan alacağı için satılan taşınmaz üzerinde satıcı,

2. Elbirliği ortaklığına giren taşınmazlarda paylaşmadan doğan alacakları için birlikte mirasçı olanlar veya diğer elbirliği ortakları,

3. Bir taşınmaz üzerinde yapılan yapı veya diğer işlerde malzeme vererek veya vermeden emek sarf ettikleri için malzeme ve emek karşılığı olarak malik veya yükleniciden alacaklı olan alt yüklenici veya zanaatkârlar ${ }^{109}$.

Yeni Medeni Kanun'da kanunî ipotek hakkının doğumu için aksi kanunda öngörülmemiş ise tapu siciline tescillerinin gerekmediğine ilişkin olan ve eski Medeni Kanun'da yer almayan bir hüküm TMK m. 892 ile kabul edilmiştir. Bir diğer ifadeyle bu madde hükmü uyarınca kanunî ipotek haklarının doğumu, aksi kanunda öngörülmüş olmadıkça, tapu kütüğüne tescil edilmelerine bağlı değildir. O halde tescile tâbi

109 “...IIKK.nun 82. maddesinin son fikrasinda hükmü sakl tutulan Medeni Kanunun 807/3. (4721 sayılı TMK m. 893) maddesine göre "bir gayrimenkul üzerindeki inşaat yahut ameliyatta malzeme vererek veya vermeyerek çalışmış olmaları hasebiyle malik veya müteahhit zimmetinde tahakkuk eden alacakları için bu kimselerin o gayrimenkul üzerinde ipotek tesisine hakları bulunmasına" nazaran, borçlunun bu ev hakkında meskeniyet iddiasinda bulunmaya hakkl yoktur..." (12. HD 28.1.1997, 143/687: Pehlivanlı s. 655); “...(M)ahkemece borçlunun 24055 parseldeki meskeninin haczedilemeyeceği şikâyetinin borcun meskeniyet iddia edilen evin inşa ve malzeme bedelinden doğduğu gerekçesiyle reddi IIIK. nun 82/12. maddesinin 2. bendi gereğince yasaya uygun ise de..." (12. HD 25.1.2007, 2006/23207-941: Oskay / Koçak / Deynekli / Doğan s. 2371). 
kanunî ipotekler mevcut olduğu (m. 893) gibi, tescile tâbi olmayan kanunî ipotekler (m. 892) de mevcuttur. İİK m. 82, II c.1 ile kanunî ipotek hakkı sahiplerinin yararların korunması amaçlandığından ve eski MK m. 807'de benzer bir düzenleme yer almadığından İ̈K m. 82, II c.1'in bundan böyle sadece eski MK m. 807'ye karşl11k gelen TMK m. 893'ü değil, aynı zamanda TMK m. 892'yi de saklı tuttuğu kabul edilmelidir ${ }^{110}$.

538 sayılı Kanun ile değişiklik yapılmadan önce 82. maddenin haczedilmeyen mallara ilişkin ayrıcalığın, borcun bu malların satış bedellerine ilişkin olması hâlinde uygulanamayacağı yolundaki ifadesinde 12. bent sayılmamışt ${ }^{111}$. Belirtmek gerekir ki, bu durum öğretide eleştirilmiş ve bunun bir unutma sonucu gerçekleşmiş olabileceği ifade edilmiştir. Bu görüşe göre borçlunun meyve veya sebze yetiştiricisi olması hâlinde, kendisinin ve ailesinin geçimleri için zorunlu olan bağ ve bahçe (m. 82/7), satıcıdan borçlanılarak alınmış ise, bu bağ veya bahçenin satıcının semen alacağı için haczine müsaade edilmiştir (İ̈K m. 82, son fikra). Sadece bu hükmün kıyas yoluyla uygulanmas1 durumunda dahi ev hacizleri hakkındaki istisnayı da buraya (İ̈K m. 82, son fikraya) dâhil saymak gerekir. Çünkü menfaatler dengesi her iki durumda da aynıdır. O nedenle borçlu, evi kredi ile satın almış ve satıcı, semen alacağından dolayı takipte bulunmuşsa borçlu bu evin hâli ile münasip bulunduğunu, bu sebeple bunun haczedilemeyeceğini semen alacaklısına karşı ileri sürememelidir ${ }^{12}$. Nitekim 538 sayılı Kanun ile 1965 yılında yapılan değişiklikle 12. bent de 82. maddenin son fikrası kapsamına alındığından bugün artık eski malikin kanunî ipotek hakkı olmasa da taşınmazın satış bedelinden doğan alacak için borçlu haczedilmezlik iddiasında bulunamayacaktır.

\footnotetext{
${ }^{110}$ Muşul, s. 519.

111 Yargıtay da bu durumu göz önünde tutmaktaydı: “...Tahsili istenen alacağın, haczolunan evin borçluya satışından doğmuş olması İIK'nun 82. maddesinin son fikrasina ithâl edilmeyen 12 sayll bent hükmü dairesinde borçlu tarafindan ileri sürülen şikâyet tetkikine mani teşkil etmeyeceği cihetle hadisede borçlunun içtimai durumu ve ailesi efradı göz önünde tutularak tetkikat yapılması lazımdır..." (IIID 13.3.1956 1512/1485: Olgaç / Köymen s. 709, No. 1760).

${ }^{112}$ Kuru-Makale s. 312.
} 


\section{SONUÇ}

Takip hukukunda borçlu borcundan dolayı kural olarak tüm malvarlığı ile sorumludur. Bununla birlikte gerek insani düşüncelerle gerekse kamu düzeni düşüncesiyle borçlunun hem kendi hem ailesinin hayatını devam ettirebilmesi için bazı malları hacizden muaf tutulmuştur. Borçlunun "hâline münasip evi" de bu kapsamda hacizden muaf tutulan mallarından biridir. Buradaki hâline münasip ev somut bir mesken olarak anlaşılmamalı; borçlunun hâline münasip ev alabileceği malvarlığı değeri olarak kabul edilmelidir. Böyle bir malvarlığı değeri bulunmayan yoksul borçlular için ise yapılacak kanun değişikliği ile onların üzerine haciz konulmuş bulunan gelirinden hâline münasip ev almaya yetecek kadar bir meblağ hacizden muaf tutulmalıdır. Takip borçlusunun evi üzerinde ipotek tesis etmesi durumunda sadece ipotek alacaklısına karşı haczedilmezlikten feragat etmiş sayılır. Buna karşılık diğer alacaklılara karşı haczedilmezlik iddiasında bulunabilir. Kanun kamu düzeni düşüncesiyle bazı malların mevcudiyetini borçlunun yaşamını sürdürebilmesi için çok önemli addettiğinden bunları tamamıla haciz kapsamı dışına çıkarmıştır. Hâline münasip ev de bu kapsamda olduğundan takip borçlusunun haczedilmezlik şikâyeti süreye bağlı değildir. Aile konutu şayet aynı zamanda borçlunun hâline münasip evi ise bu durumda takip borçlusu eşinin rızası olmaksızın evin haczedilmezliğinden feragat edemez. 


\section{KAYNAKÇA}

Ansay, Sabri Şakir. (1954). Hukuk İcra ve Iflas Usulleri. 3. Ankara.

Arar, Kemal. (1944). İcra ve Iflas Hükümleri. Ankara.

Arslan, Ramazan. (1991). Alacakların Tahsili Hususunda Cebri İcra ve Yargılama Anında Karşılaşılan Sorunlar ve Çözüm Yolları, (Alacakların Tahsili Hususunda Cebri İcra ve Yargılama Aşamasında Karşılaşılan Sorunlar ve Çözüm Yolları, 5-7 Temmuz 1991, Abant Palace, s. 7-24).

Aslan, Kudret (2005). Hacizde Sira (Tertip) $A \ddot{U} H F D$, S. 2, s. 269-318.

Aşık, İbrahim (2006). İcra Sözleşmeleri. Ankara.

Atalay, Oğuz. (2002). Türk Medeni Kanunu'nda Aile Hukuku Mal Rejimlerine İlişkin Hükümlerin Takip Hukuku Bakımından Değerlendirilmesi, Medeni Usul ve İcra-Iflas Hukukçuları Toplantısı, Eskişehir 9-10 Kasım 2002, s. 51-73.

Aytemiz, Abdullah. (1944). Takip Hukuku ile Alakalı Temyiz Karar ve İçtihatları, Ankara.

Başöz, Lütfü/Çakmakçı, Ramazan. (2003). Gerekçeli, Karşılaştırmalı, Atıflı İcra ve İflas Kanunu ve İlgili Mevzuat. İstanbul.

Başözen, Ahmet. İflas Tasfiyesinde Müflisin Kişisel Çalışmasına Dayalı Malların Durumu - "Müflisin Uhdesine Geçen Mal" Kavramı (İ̈K m. 184, I) (AÜHFD, C. 54, 2005/4, s. 267-297).

Belgesay, Mustafa Reşit. İcra ve İflas Kanunu Şerhi, 4. B., İstanbul 1954.

Berkin, Necmeddin M.. Haczi Caiz Olmayan Eşya ve Alacaklar (IBD 1957/5, s. 113-124), (Berkin-Makale).

Berkin, Necmeddin M. (1969). İcra Hukuku Dersleri. 2. B. İstanbul.

Berkin, Necmeddin, M. (1947). İcrada Hukuk. İstanbul.

Berkin, Necmeddin M. (1980). Tatbikatçllara İcra ve İflas Hukuku Rehberi, İstanbul. 
Dönmez, Murat. Aile Konutunun Haczi (TBBD, Temmuz-Ağustos 2008/77, s. 349-358).

Dönmez, Murat. (2009). İcra ve İflâs Hukukunda Meskeniyet İddiası (İIK m. 82/12), İzmir.

Eriş, Gönen. (2005). Gerekçeli-Açıklamal1-İçtihatlı İcra ve İflas Kanunu, Ankara.

Gümüş, Alper. (2007). Türk Medeni Kanunu'nun Getirdiği Yeni Şerhler, 2. B. İstanbul.

Kaçak, Nazif. (2006). Açıklama ve İçtihatlarla Haczedilmezlik, Ankara 2006.

K1lıçoğlu, Evren. (2005). İcra Sözleşmeleri, İstanbul. 2005.

Kiraz, Taylan Özgür. İsviçre Federal Mahkemesinin Bir Kararı Çerçevesinde Takip Hukukunda Şikâyet Eden Taraf Bakımından İlgili Kavramı (Prof. Dr. Bilge Öztan'a Armağan, Ankara 2008, s. 561-566).

Korkud, Halit. Haciz Edilen Gayri Menkullerde Meskeniyet İddia ve Şikâyetleri (IBDD 1944/4, s. 193-195).

Korkusuz, Refik M. (2004). İcra Hukuku ve Uygulaması, Ankara.

Kuru, Baki. Haczi Caiz Olmayan Şeyler (AÜHFD 1962/1-4, s. 277-326), (Kuru-Makale).

Kuru, Baki. (1990). İcra ve İflas Hukuku, I, 3. B., İstanbul.

Kuru, Baki. (2004). İcra ve İflas Hukuku El Kitabı, İstanbul (Kuru-El Kitab1).

Kuru, Baki/Arslan, Ramazan/Yılmaz, Ejder. (2009). İcra ve İflas Hukuku Ders Kitab1, 23. B., Ankara 2009.

Muşul, Timuçin. (2009). İcra ve İflas Hukuku, 3. B. Ankara.

Olgaç, Senai (1978). İcra-İflas, C. 1-2, Ankara. 
Olgaç, Senai/Köymen,Haydar (1965). Kazai ve İlmi İçtihatlarla Türk İcra ve İflas Kanunu, 2. B., İstanbul.

Oskay, Mustafa/Koçak, Coşkun/Deynekli, Adnan/ Doğan, Ayhan. (2007). İIK. Şerhi, C. 2, Ankara.

Özbay, İbrahim : İcra ve İflas Hukukumuzda Haczedilmezlikten Feragat (İ̈K m. 83/a).

Özekes, Muhammet (2009). İcra Hukukunda Temel Haklar ve İlkeler, Ankara.

Özkan, Hasan. (1999). İcra ve İflas Davaları Tatbikatı, Ankara.

Özmumcu, Seda. İcra ve İflas Müdürlerinin Takdir Hakk1 (Prof. Dr. Turgut Akıntürk'e Armağan, İstanbul 2008, s. 489-514).

Pehlivanlı, M. Gündüz. (1998). Açılamalı İcra ve İflas Kanunu, C. 1, Ankara.

Pekcanıtez, Hakan. (1986). İcra-İflas Hukukunda Şikâyet, Ankara.

Pekcanıtez, Hakan/Atalay, Oğuz/Sungurtekin Özkan, Meral/Özekes, Muhammet. (2008). İcra ve İflas Hukuku, 6. B., Ankara.

Postacıoğlu, İlhan E. (1982). İcra Hukuku Dersleri, İstanbul.

Seviğ, Vasfi Raşit (1967). Doktrin ve İçtihatlar Açısından Türk İcra ve İflas Kanunu-İcra, C. II, Ankara.

Sungurtekin Özkan, Meral. İcra Hukukunda Oranlılık İlkesi (Prof. Dr. Turhan Tufan Yüce’ye Armağan, İzmir 2001, s. 177-203).

Şıpka, Şükran. (2004). Aile Konutu ile İlgili Diğer İşlemlerde Diğer Eşin Rizası, 2. B., İstanbul.

Taşpınar, Sema. (1994). Borçlunun Bazı Mallarının Haczedilememesi ve Nedenleri (Haczedilmezlik ve Nedenleri), (Yayımlanmamış Yüksek Lisans Tezi), Ankara (Taşpınar-Tez). 
Taşpınar, Sema. İsviçre Federal İcra ve İflâs Kanunu'nda Yapılan Değişikliklere Genel Bir Bakış (75. Yaş Günü İçin Prof. Dr. Baki Kuru Armağanı, Ankara 2004, s. 599-670), (Taşpınar-Armağan).

Ulukapı, Ömer. İcra ve İflas Hukuku, 1. B., Konya 2001.

Ulukapı, Ömer. Haczedilmezlik ve Haczedilmezliğin "4046 Sayılı Özelleştirme Kanunu” Kapsamındaki Uygulaması (BATIDER, C. XVIII, S. 1995/1-2, s. 137-150).

Umar, Bilge. (1973). İcra ve İflas Hukukunun Tarihi Gelişmesi ve Genel Teorisi, İzmir.

Uyar, Talih. (1990). İcra Hukukunda Haciz, 2. B., Manisa.

Uyar, Talih. Haczi Caiz Olmayan Mallar ve Haklar (İK m. 82) (Dr. A. Recai Seçkin'e Armağan, Ankara 1974, s. 551-586).

Uyar, Talih. (2004). Gerekçeli-Içtihatlı İcra ve İflas Kanunu Şerhi, C. 5, 3. B., Ankara.

Üstündağ, Saim. (2004). İcra Hukukunun Esasları, 8. B., İstanbul.

Yalçın, Mehmet. (2009). İcra ve İflas Hukukunda Mesken Haczi (Yayımlanmamış Yüksek Lisans Tezi), İstanbul.

Yıldırım, Kamil/Deren-Yıldırım, Nevhis. (2009). İcra Hukuku, 4. B., İstanbul. 